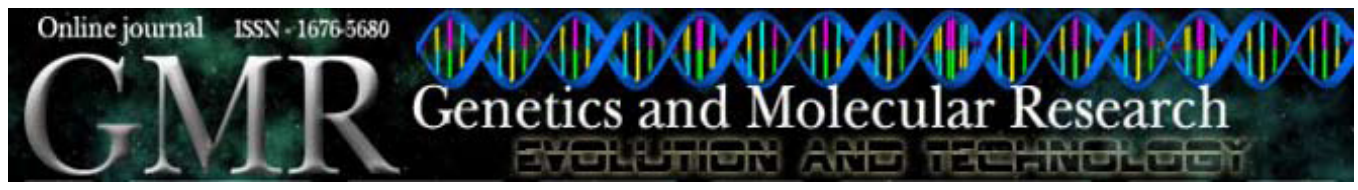

\title{
Hygienic behavior of the stingless bee Plebeia remota (Holmberg, 1903) (Apidae, Meliponini)
}

\author{
P. Nunes-Silva ${ }^{1}$, V.L. Imperatriz-Fonseca ${ }^{2}$ and L.S. Gonçalves ${ }^{2}$ \\ ${ }^{1}$ Departamento de Ecologia, Instituto de Biociências, \\ Universidade de São Paulo, São Paulo, SP, Brasil \\ ${ }^{2}$ Departamento de Biologia, Faculdade de Filosofia, \\ Ciências e Letras de Ribeirão Preto, \\ Universidade de São Paulo, Ribeirão Preto, SP, Brasil
}

Corresponding author: P. Nunes-Silva

E-mail: pnsilva@ib.usp.br

Genet. Mol. Res. 8 (2): 649-654 (2009)

Received December 12, 2008

Accepted January 26, 2009

Published June 2, 2009

ABSTRACT. We investigated hygienic behavior in 10 colonies of Plebeia remota, using the pin-killed method. After $24 \mathrm{~h}$ the bees had removed a mean of $69.6 \%$ of the dead brood. After $48 \mathrm{~h}$, the bees had removed a mean of $96.4 \%$ of the dead brood. No significant correlation was found between the size of the brood comb and the number of dead pupae removed, and there was no apparent effect of the origin and the condition of the colony on the hygienic behavior of the bees. Plebeia remota has an efficiency of hygienic behavior superior to that of three of the other four stingless bee species studied until now.

Key words: Plebeia remota; Stingless bees; Hygienic behavior 


\section{INTRODUCTION}

Apis mellifera workers are capable of detecting diseased, infected, damaged or dead brood, uncapping the cells and removing the affected larvae and pupae. This capability is known as hygienic behavior (Rothenbuhler, 1964a,b); since this behavior makes honey bees more resistant to diseases and parasites, it has become of great interest for apiculture (see Boecking and Spivak, 1999).

Hygienic behavior had been considered exclusively a characteristic of A. mellifera (Michener, 1974). Some species of stingless bees also have this capability, though it has been little investigated. The only stingless bee species whose hygienic behaviors have been measured so far are Melipona beecheii, Scaptotrigona pectoralis (Medina and Ratnieks, 2001), Melipona quadrifasciata and Tetragonisca angustula (Tenório, 1996). Differences in efficiency were found among the species. While S. pectoralis removed $97 \%$ of dead brood within $48 \mathrm{~h}, T$. angustula, M. beecheii and M. quadrifasciata removed only 10,66 , and 1\%, respectively, using the freeze-killed brood assay. Tenório (1996) found different results for the same species using the pin-killing method. The bees removed the dead brood faster when the brood was killed by freezing.

These studies did not relate the behavior of removing the dead brood to a disease. Nogueira-Neto (1999) reported a case of mortality of late-stage larvae or prepupae of Scaptotrigona postica, T. angustula, Plebeia spp, Cephalotrigona capitata, and M. quadrifasciata, as well as the response of adult M. quadrifasciata workers: they either removed the cell caps but left the dead immatures inside them, removed the dead immatures from the cells but left them on the surface of the brood combs, or they removed the dead immatures from the colony. He also observed holes in the brood combs in the affected colonies. These holes were due to removed cells. The response of the colonies to this disease problem was not homogenous; each colony had a different response. Some were more affected than others. There is strong evidence that hygienic behavior of stingless bees is a reaction to diseases and might play an important role on disease control.

Although there have been some reports about diseases in stingless bees, especially by Nogueira-Neto (1999), there have been virtually no studies about them.

We examined the hygienic behavior in a Brazilian stingless bee, Plebeia remota, and determined the efficiency of this behavior. We also examined some factors (strength of the colony based on population size and number of food pots) that could influence this efficiency.

\section{MATERIAL AND METHODS}

\section{Plebeia remota}

This species is found in the southern part of Brazil, occurring in the States of Minas Gerais, São Paulo, Paraná, Santa Catarina, and Rio Grande do Sul (Wittmann and Hoffmann, 1990; Silveira et al., 2002; Mouga, 2004). Its behavior has been studied for more than 10 years, mainly foraging (Imperatriz-Fonseca, 1985; Hilário, 2005; NunesSilva, 2007) and reproductive diapause, a period when the bees do not construct brood cells and the queen does not oviposit (van Benthem et al., 1995; Ribeiro et al., 2003). In general, diapause begins in April and finishes in August (Ribeiro et al., 2003). 


\section{Methods}

Ten colonies of $P$. remota were used in the experiment; five were from Cunha $\left(23^{\circ} 05^{\prime} \mathrm{S}\right.$,

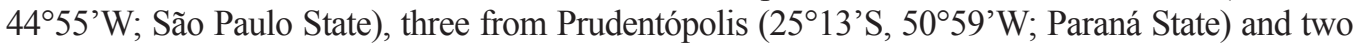
from natural swarms captured at the University of São Paulo Campus in São Paulo (233's, $\left.46^{\circ} 43^{\prime} \mathrm{W}\right)$. Seven were installed inside lab facilities and three were located outside. The colonies were housed inside wood nest boxes, and those installed inside the lab facilities had flight tubes to the outside. The nests were not artificially heated and during the experiments the bees were not artificially fed. The tests were made in March 2006, at the end of the summer and approximately one month before the beginning of reproductive diapause.

The colonies were classified, by comparison, as weak, medium or strong, according to the size of population (number of bees: few, average or numerous) and the number of food pots (few, average or numerous). The pin-killing method (Newton and Ostasiewski Jr., 1986; Gramacho and Gonçalves, 1994) was used to measure hygienic behavior. Twenty-five brood cells (containing pupae) were used in each treatment ( 25 perforated cells and 25 non-perforated cells - control). The relationship between brood comb size (in number of cells) and the number of killed pupae removed after 24,48 , and $120 \mathrm{~h}$ was analyzed by the Spearman correlation coefficient.

\section{RESULTS}

Plebeia remota displayed hygienic behavior as a reaction to killed brood; no colonies removed brood cells from the control region of the comb. After $24 \mathrm{~h}$, the bees removed a mean of $69.6 \%$ of all the dead brood. Some colonies (40\%) did not remove all the dead brood within $24 \mathrm{~h}$, but did so within $48 \mathrm{~h}$. At $48 \mathrm{~h}$, the bees had removed a mean of $96.4 \%$ of the dead brood (Figure 1; Table 1).

There was no significant correlation between the number of cells removed and the size of the brood comb $(\mathrm{r}=0.34, \mathrm{P}=0.33)$. Also, there was no apparent effect of colony origin and condition (weak, medium or strong) on the hygienic behavior of the bees. Possibly, maintaining the colony inside or outside the lab may have influenced the results (Table 1); however, a greater number of colonies would need to be evaluated to determine if such an effect exists.

While the brood comb was removed and manipulated, some cells often became accidentally uncapped, because of the pillars of cerumen that connect the combs to the pots and the walls of the hive. These uncapped cells were capped again within $24 \mathrm{~h}$, indicating that damage to the capping is not a stimulus for removing the brood.

\section{DISCUSSION}

Plebeia remota, as found for the four other species of stingless bee studied, displayed hygienic behavior when killed brood was present. However, this behavior was not related to any parasite or disease. Currently, virtually no disease or parasite of stingless bees is known.

This species removed more dead brood than Melipona beecheii (66\%), and had an efficiency similar to Scaptotrigona pectoralis (97\%; Medina and Ratnieks, 2001). After 120 h, only one colony had not removed all dead brood. Plebeia remota was faster at removing dead brood than M. beecheii (nine days to remove 100\%), but slower than S. pectoralis (three days; Medina and Ratnieks, 2001). 


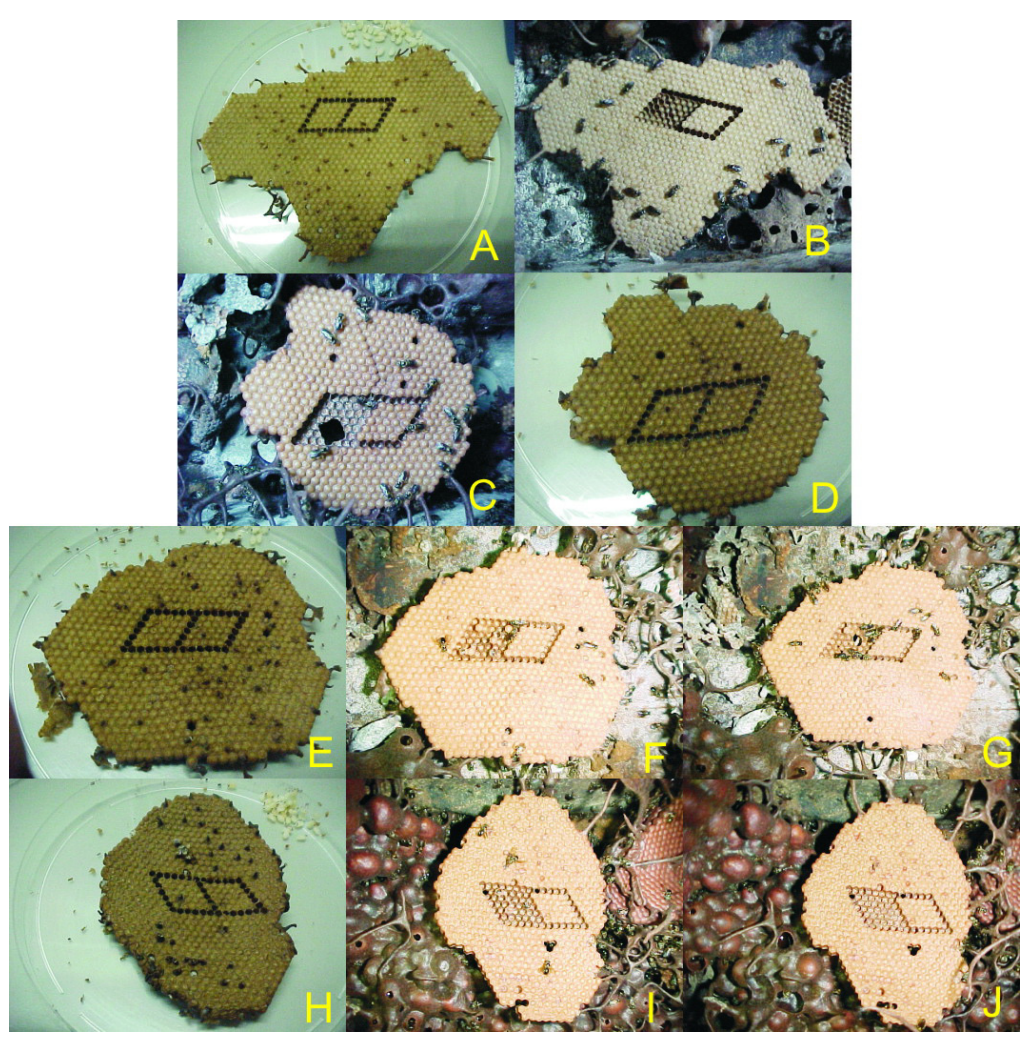

Figure 1. Result of the hygienic behavior test performed in Plebeia remota colonies. Colony I: A. Comb with pinkilled brood on the left side; B. Comb $24 \mathrm{~h}$ after the return to the nest. Colony H: C. Comb with pin-killed brood on the left side; D. Comb $24 \mathrm{~h}$ after the return to the nest. Colony D: E. Comb with pin-killed brood on the left side; F. Comb $24 \mathrm{~h}$ after the return to the nest; G. Comb $48 \mathrm{~h}$ after the return to the nest. Colony E: H. Comb with pin-killed brood on the left side; I. Comb $24 \mathrm{~h}$ after the return to the nest; J. Comb $48 \mathrm{~h}$ after the return to the nest.

Table 1. Percentage pin-killed brood cells uncapped and with brood removed in the treatment area after 24, 48 and $120 \mathrm{~h}$, depending on the location and the conditions of the colonies of Plebeia remota.

\begin{tabular}{lcccccccc}
\hline Colony & $24 \mathrm{~h}(\%)$ & $48 \mathrm{~h}(\%)$ & $120 \mathrm{~h}(\%)$ & $\begin{array}{c}\text { Location } \\
\text { of the hive }\end{array}$ & $\begin{array}{c}\text { Number } \\
\text { of bees }\end{array}$ & $\begin{array}{c}\text { Quantity } \\
\text { of food pots }\end{array}$ & $\begin{array}{c}\text { Colony } \\
\text { condition }\end{array}$ & $\begin{array}{c}\text { Brood } \\
\text { comb size }\end{array}$ \\
\hline A & 0 & 96 & 100 & Inside & Few & Few & Weak & 355 \\
B & 0 & 72 & 100 & Outside & Average & Average & Medium & 596 \\
C & 40 & 100 & 100 & Outside & Few & Few & Weak & 503 \\
D & 76 & 96 & 96 & Inside & Numerous & Average & Medium & 839 \\
E & 92 & 100 & 100 & Inside & Numerous & Numerous & Strong & 700 \\
F & 92 & 100 & 100 & Inside & Average & Average & Medium & 493 \\
G & 96 & 100 & 100 & Outside & Average & Few & Weak & 601 \\
H & 100 & 100 & 100 & Inside & Numerous & Numerous & Strong & 1084 \\
I & 100 & 100 & 100 & Inside & Numerous & Few & Medium & 634 \\
J & 100 & 100 & 100 & Inside & Numerous & Average & Medium & 483 \\
\hline
\end{tabular}

${ }^{1}$ Inside or outside the laboratory; ${ }^{2}$ number of cells. 
Plebeia remota proved to be more efficient at removing dead brood than M. quadrifasciata (around $1 \%$ after $72 \mathrm{~h}$, in relation to pupae with white eyes) and Tetragonisca angustula (around 10\% after $48 \mathrm{~h}$ and 30\% after $72 \mathrm{~h}$, for pupae with white eyes; Tenório, 1996), at least in removing pupae killed with the pin-killing method. Tenório (1996) also tested the hygienic behavior of these species with the freeze-killed brood assay, using two larval stages. Except for the tests with freeze-killed brood, P. remota removed dead brood faster than did M. quadrifasciata and T. angustula. It appears that Melipona species are slower at removing dead brood than do $S$. pectoralis, $P$. remota and $T$. angustula, and thus have a less efficient hygienic behavior. However, we do not know why there are such differences between species. One hypothesis is that different species have distinct sensitivities and consequently different responses to dead or diseased brood, as do hygienic and non-hygienic bees (Masterman et al., 2000,2001 ) and hygienic bees of different ages (Gramacho and Spivak, 2003). Another factor affecting hygienic behavior is the internal state of the colony, at least in honey bees (Spivak and Gilliam, 1993). Consequently, the population of the colonies could be one of the reasons why there are differences in the performance of hygienic behavior among different species. We found no apparent relationship between the internal condition of the colony and the efficiency of hygienic behavior in P. remota; however, this aspect deserves more detailed study.

These bees are capable of detecting and distinguishing dead brood, as indicated by the recapping of the cells containing live brood, and damages to the cell caps do not stimulate removal. The recapping of cells with undamaged or dead brood was previously observed in $A$. mellifera (Gramacho, 1995; Corrêa-Marques and De Jong, 1998).

We conclude that Plebeia remota is capable of effective hygienic behavior, which confirms that this behavior exists in stingless bees, acting as a mechanism of resistance against disease, as stated by Medina and Ratnieks (2001). The hygienic behavior of this and other stingless bee species deserves more detailed study, as do stingless bee diseases.

\section{ACKNOWLEDGMENTS}

We thank Dr. David De Jong for language correction and important suggestions and Tiago M. Francoy for helping with the figures. We also thank CNPq for financial support (\#135074/2005-3).

\section{REFERENCES}

Boecking O and Spivak M (1999). Behavioral defenses of honey bees against Varroa jacobsoni Oud. Apidologie 30: 141-158. Corrêa-Marques MH and De Jong D (1998). Uncapping of worker bee brood, a component of the hygienic behavior of Africanized honey bees against the mite Varroa jacobsoni Oudemans. Apidologie 29: 283-289.

Gramacho KP (1995). Estudo do Comportamento Higiênico em Apis mellifera como Subsídio a Programas de Seleção e Melhoramento Genético em Abelhas. Master's thesis, Faculdade de Filosofia, Ciências e Letras de Ribeirão Preto, Universidade de São Paulo, Ribeirão Preto.

Gramacho KP and Gonçalves LS (1994). Estudo Comparativo dos Métodos de Congelamento e Perfuração de Crias para Avaliação do Comportamento Higiênico em Abelhas Africanizadas. In: IV Congresso Latinoiberoamericano de Apicultura, 5, 1994, Córdoba, Anais, 45.

Gramacho KP and Spivak M (2003). Differences in olfactory sensitivity and behavioral responses among honey bees bred for hygienic behavior. Behav. Ecol. Sociobiol. 54: 472-479.

Hilário SD (2005). Atividade de vôo e termorregulação de Plebeia remota (Holmberg,1903) (Hymenoptera, Apidae, Meliponini). PhD thesis, Bioscience Institute, University of São Paulo, São Paulo. 
Imperatriz-Fonseca VL, Kleinert-Giovannini A and Pires JT (1985). Climate variations influence on the flight activity of Plebeia remota Holmberg (Hymenoptera, Apidae, Meliponinae). Rev. Bras. Entomol. 29: 427-434.

Masterman R, Smith BH and Spivak M (2000). Brood odor discrimination abilities in hygienic honey bees (Apis mellifera L.) using proboscis extension reflex. J. Insect Behav. 13: 87-101.

Masterman R, Ross R, Mesce K and Spivak M (2001). Olfactory and behavioral response thresholds to odors of diseased blood differ between hygienic and non-hygienic honey bees (Apis mellifera L.). J. Comp. Physiol. 187: 441-452.

Medina ML and Ratnieks FLW (2001). Comportamiento Higienista en Melipona beecheii y Scaptotrigona pectoralis (Hymenoptera: Meliponinae). In: II Seminario Mexicano sobre Abejas sin Aguijón. 9-10 Noviembre de 2001, Anais eletrônicos, CD-ROM, Mérida.

Michener CD (1974). The Social Behavior of the Bees. Harvard University Press, Cambridge.

Mouga DMDS (2004). As comunidades de abelhas (Hymenoptera, Apoidea) em Mata Atlântica na região nordeste do Estado de Santa Catarina, Brasil. Doctoral thesis, Biosciences Institute, University of São Paulo, São Paulo.

Newton DC and Ostasiewski NJ Jr (1986). A simplified bioassay for behavioural resistance to American foulbrood in honey bees (Apis mellifera L.). Am. Bee J. 126: 278-281.

Nogueira-Neto P (1999). Vida e Criação de Abelhas Indígenas sem Ferrão. Nogueirapis, São Paulo.

Nunes-Silva P (2007). A Organização e a Ritmicidade no Forrageamento e na Enxameação de Plebeia remota (Holmberg, 1903) (Hymenoptera, Apidae, Meliponini). [The Organization and Rhythm in the Foraging and Swarming of Plebeia remota (Holmberg, 1903) (Hymenoptera, Apidae, Meliponini)]. Master's thesis, Biosciences Institute, University of São Paulo, São Paulo.

Ribeiro MF, Imperatriz-Fonseca VL and Santos Filho PS (2003). A Interrupção da Construção de Células de Cria e Postura em Plebeia remota (Holmberg) (Hymenoptera, Apidae, Meliponini). In: Apoidea Neotropica: Homenagem aos 90 Anos de Jesus Santiago Moure (Melo GAR and Alves dos Santos I, eds.). Editora UNESC, Criciúma, 177-188.

Rothenbuhler WC (1964a). Behaviour genetics of nest cleaning in honey bees. I. Responses of four inbred lines to diseased-killed brood. Anim. Behav. 5: 578-583.

Rothenbuhler WC (1964b). Behavior genetics of genetics of nest cleaning in house bees. IV. Responses of F1 and backcross generations to disease-killed blood. Am. Zool. 4: 111-123.

Silveira FA, Melo GAR and Almeida EAB (2002). Abelhas Brasileiras: Sistemática e Identificação. 1st edn. Fundação Araucária, Belo Horizonte.

Spivak M and Gilliam M (1993). Facultative expression of hygienic behaviour of honey bees in relation to disease resistance. J. Apic. Res. 32: 147-157.

Tenório EG (1996). Comportamento Higiênico em Abelhas Indígenas (Melipona quadrifasciata Lepeletier, 1836 e Tetragonisca angustula Latreille, 1811) e em Abelhas Africanizadas (Apis mellifera Linnaeus, 1758). Master's thesis, Universidade Federal de Viçosa, Viçosa.

van Benthem FDJ, Imperatriz-Fonseca VL and Velthuis HHW (1995). Biology of the stingless bee Plebeia remota (Holmberg). Observations and evolutionary implications. Insectes Soc. 42: 71-87.

Wittmann D and Hoffmann M (1990). Bees of Rio Grande do Sul, southern Brazil (Insecta, Hymenoptera, Apoidea). Iheringia, Ser. Zool. 70: 17-43. 